\title{
JOYFUL LEARNING: STRATEGI ALTERNATIF MENUJU PEMBELAJARAN MENYENANGKAN
}

\author{
Sufiani \\ Institut Agama Islam Negeri (IAIN) Kendari \\ sufiani1969@gmail.com \\ Marzuki \\ Institut Agama Islam Negeri (IAIN) Kendari \\ marzuki1965@yahoo.com
}

\begin{abstract}
Abstrak
Artikel ini merupakan hasil kajian kepustakaan yang bertujuan untuk menganalisis strategi pembelajaran menyenanggkan dengan Joyful Learning. Banyak mata pelajaran di sekolah/madrasah berisi konsep-konsep teoritis dan untuk menguasainya membutuhkan memori otak untuk menghafalnya. Proses menghafal tersebut seringkali menimbulkan kesan bahwa mata pelajaran tersebut menjadi tidak menarik dan membosankan. Bagi peserta didik yang tidak suka menghafal, maka mata pelajaran yang demikian menjadi sulit untuk dikuasai sehingga tujuan pembelajaran yang telah ditetapkan tidak tercapai yang berimplikasi pada ketidaktuntasan dalam hasil belajar. Melihat situasi yang demikian,maka guru yang profesional perlu menggunakan strategi yang tepat agar pembelajaran yang dilaksanakan berlangsung dengan aktif, kreatif, efektif dan menyenangkan. Salah satu strategi yang perlu diterapkan oleh guru dalam pelaksanaan pembelajaran adalah joyful learning (pembelajaran menyenangkan). Menerapkan strategi pembelajaran joyful learnig pada prinsipnya sesuai dengan anjuran pemerintah bahwa guru yang profesional berkewajiban untuk menciptakan suasana pembelajaran yang bermakna, menyenangkan, kreatif, dinamis dan dialogis. Hal yang lebih penting lagi bahwa proses pembelajaran pada jenjang dan jenis pendidikan harus diselenggarakan secara inspiratif, interaktif, memotivasi peserta didik untuk berpartisipasi aktif, memberikan ruang gerak yang cukup untuk berprakarsa, mengembangkan kreativitas dan kemandirian sesuai dengan bakat, minat, perkembangan fisik dan psikologis peserta didik.
\end{abstract}

Kata Kunci : Joyful Learning, Strategi Pembelajaran, Pembelajaran Menyenangkan.

\begin{abstract}
Many subjects in school / madrasah contain theoretical concepts and to master them requires brain memory to memorize them. This memorization process often creates the impression that the subject becomes uninteresting and boring. For students who do not like to memorize, such subjects become difficult to master so that the learning objectives that have been set are not achieved which has implications for incompleteness in learning outcomes. Seeing this situation, professional teachers must use the right strategy so that learning is carried out actively, creatively, effectively and pleasantly. One of the strategies that need to be applied by the teacher in implementing learning is joyful learning (fun learning). Implementing joyful learning strategies is in principle in accordance with the government's recommendation that professional
\end{abstract}


teachers are obliged to create a learning atmosphere that is meaningful, fun, creative, dynamic and dialogical. It is even more important that the learning process at the level and type of education must be organized in an inspirational, interactive manner, motivating students to actively participate, providing sufficient space for initiatives, developing creativity and independence according to the talents, interests, physical and psychological development of the participants. students.

Keywords : Joyful Learning, Learning Strategies, Fun Learning.

\section{Pendahuluan}

Pendidikan memegang peranan yang sangat penting untuk kemajuan suatu bangsa termasuk Indonesia karena tanpa adanya pendidikan yang berkualitas dan bermutu,maka mustahil suatu bangsa akan maju dan berperadaban. Dalam UndangUndang Sistem Pendidikan Nasioanal Bab II Pasal 3 dikemukakan bahwa pendidikan nasional berfungsi untuk mengembangkan kemampuan dan membentuk watak serta peradaan bangsa yang bermartabat dalam rangka mencerdaskan kehidupan bangsa (Departemen Agama RI, 2006). Untuk mewujudkan fungsi pendidikan tersebut dalam rangka mencapai tujuan pendidikan nasional yang dicita-citakan, diperlukan keterlibatan berbagai unsur serta komponen bangsa dan salah satu diantaranya yang menggeluti bidang pendidikan yaitu tenaga pendidik (guru).

Guru dalam dunia pendidikan sangat penting tugas dan fungsinya karena dalam profesi guru mereka sebagai pendididik, pelatih dan pengajar, sedangkan dalam bidang kemanusian, guru menjadikan dirinya sebagai orang tua di sekolah/madrasah dan dalam bidang kemasyarakatan, guru menjadikan dirinya pada tempat yang terhormat di lingkungannya. Penanaman nilai menjadi turbin yang menggerakkan anak untuk memiliki pengalaman sejak dini, agar anak tumbuh menjadi pribadi-pribadi yang memiliki integritas moral, sehingga mereka bisa menyesuaikan diri dengan lingkungan dimana mereka hidup dan berkembang (Andreas Putra et al., 2020). Oleh karena itu, guru dituntut untuk dapat menjalankan tugas dan fungsinya baik secara professional maupun sosial.

Dalam hal menjalankan tugas dan fungsinya secara profesional sebagai seorang pendidik, pengajar dan pelatih, maka guru perlu menerapkan strategi pembelajaran yang tepat, yang sesuai dengan karakteristik peserta didik dan karakteristik mata pelajaran. Dengan demikian proses pembelajaran tidak dilakukan dengan monoton tapi dapat dilakukan dengan variasi strategi pembelajaran. 
Upaya yang ideal yang dilakukan oleh seorang guru agar pembelajaran berlangsung dengan efektif dan menyiapkan lulusan yang berkualitas, salah satunya adalah menerapkan strategi joyful learning (pembelajaran yang menyenangkan). Pembelajaran yang menyenangkan merupakan suatu strategi dan konsep pembelajaran yang merupakan perpaduan dari pembelajaran yang bermakna, kontekstual, kontruktivistik, aktif dan psikologis. Peserta didik akan bersemangat dan gembira dalam kegiatan pembelajaran karena peserta didik mengetahui makna serta kegunaan dari belajar. Peserta didik belajar sesuai dengan bakat dan minatnya dengan memadukan konsep pembelajaran yang sedang dipelajarinya dengan kenyataan dalam kehidupan sehari-hari bahkan dengan berbagai masalahh-masalah aktual yang terjadi dan berkembang di masyarakat.

Pendidikan seyogyanya dapat menghadirkan suasana pembelajaran yang menyenangkan, bermakna dan dinamis. Hal tersebut seiring dengan kewajiban guru yang termaktub dalam Undang-Undang Nomor 20 Tahun 2003 pasal 40 bahwa: pendidik berkewajiban untuk menciptakan suasana pendidikan yang bermakna, menyenangkan, kreatif, dinamis dan dialogis. Pendidik pula mempunyai komitmen secara profesional untuk meningkatkan mutu pendidikan serta memberi teladan dan menjaga nama baik lembaga, profesi dan kedudukannya sesuai dengan kepercayaan yang diberikan kepadanya (Departemen Agama RI, 2006). Dengan demikian guru berkewajiban melaksanakan pembelajaran yang berorientasi pada peserta didik agar mereka merasa senang dan bahagia dalam pelaksanaan pembelajaran sesuai dengan profesinya sebagai pendidik.

Sehubungan dengan pernyataam di atas, Mulyasa menjelaskan bahwa pembelajaran menyenangkan akan selalu menggugah rasa ingin tahu peserta didik termasuk materi pembelajaran. Apabila pembelajaran dapat dikondisikan dalam suasana yang menyenangkan maka peserta didik akan aktif dan kreatif dalam proses pembelajaran(Mulyasa, 2006). Menurut Wahyuni dkk, Anak akan memiliki kemampuan untuk mengatur dan mengenali dirinya sendiri dalam proses pembelajaran (Anhusadar \& Wulandari, 2019). Konsep atau teori yang dikemukakan tersebut apabila aplikasinya diterapkan oleh guru yang profesional maka akan menjadikan suasana pembelajaran yang menyenangkan dengan berbagai pilihan metode dan teknik dalam pembelajaran. Beberapa metode pembelajaran yang menyenangkan diantaraya examples non 
examples, snowball throwing, numbered heads together, jigwawdan lain-lain. Sementara teknik pembelajaran yang sangat digemari oleh peserta didik adalah humor. Dengan humor dapat merangsang daya pikir dan daya serap peserta didik sehingga dapat meningkatkan hasil belajarnya.

Tulisan ini menggambarkan bahwa strategi pembelajaran joyful learning sebagai sebuah strategi pembelajaran yang berusaha untuk membangkitkan minat, adanya keterlibatan penuh, dan terciptanya makna, pemahaman nilai yang membahagiakan pada diri peserta didik. Masitoh dan Dewi menjelaskan bahwa pemahaman nilai yang membahagiakan pada diri peserta didik karena pembelajaran yang di dalamnya tidak ada lagi tekanan, baik tekanan fisik maupun psikis sehinggatercipta suasana kelas yang menyenangkan dan tidak monoton (Laksmi \& Dewi, 2009). Sementara Wahono menggambarkan strategi pembelajaran joyful learning menjadikan proses pembelajaran yang mengasyikkan dan bermakna. Mengasyikkan berarti pembelajaran yang dapat dinikmati oleh peserta didik tanpa adanya tekanan, sedangkan bermakna berarti pengetahuan dan keterampilan yang diperoleh peserta didik dalam pembelajaran dapat bermanfaat dalam kehidupannya (Wahono, 2012) .

Secara umum, permasalahan yang selalu dihadapi peserta didik dalam proses pembelajaran dewasa ini adalah guru yang masih menggunakan model, strategi dan metode pembelajaran yang membosankan peserta didik. Model, strategi dan metode pembelajaran yang digunakan oleh guru dalam pelaksanaan pembelajaran masih sering berasal dari satu arah yakni pembelajaran hanya berpusat pada guru. Selain dari pada itu guru pula kurang memahami karakteristik peserta didik dan karakteistik mata pelajaran. Akibatnya peserta didik menjadi bosan sehingga tidak bersemangat dalam mengikuti proses pembelajaran.

Untuk mengantisipasi keadaan seperti disebutkan di atas maka guru yang profesional harus melaksanakan berbagai upaya dengan menerapkan berbagai strategi pembelajaran agar peserta didik memiliki motivasi yang kuat dalam pelaksanaan pembelajaran. Salah satu upaya yang dilakukan oleh guru dalam proses pembelajaran adalah menggunakan strategi joyful learning. Penulis lain juga telah melakukan penelitian tentang pembelajaran yang menyenangkan dari Universitas Negeri Makassar dengan judul "pembelajaran kreatif dan menyenangkan" namun masih bersifat umum dan belum menyentuh pada stategi khusus dalam pembelajaran yakni joyful learning. 
Bahkan lebih jauh lagi, masalah ini pernah ditulis dalam jurnal "inspirasi pendidikan " pada Universiti Utara Malaysia, namun sifatnya masih umum pula. Penulis dalam artikel ini ingin menampilkan strategi khusus dalam pelaksanaan pembelajaran yang dilakukan oleh guru agar pelaksanaannya dapat menyenangkan yakni strategi pembelajaran joyful learning. Oleh karena itu tuilsan ini akan mengurai tentang tujuan strategi pembelajaran joyful learning, teknik strategi pembelajaran joyful learning, langkah-langkah strategi pembelajaran joyful learning, urgensi strategi pembelajaran joyful learning dan strategi pembelajaran joyful learning sebagai upaya meningkatkan mutu pembelajaran.

\section{Pengertian Strategi Pembelajaran Joyful Learning}

Strategi pembelajaran joyful learning adalah strategi pembelajaran yang digunakan oleh guru dalam proses pembelajaran sebagaiusaha untuk membangkitkan minat peserta didikagar mereka terlibat secara penuh dalam pelaksanaan pembelajaran dalam upaya penanaman makna, pemahaman nilai yang membahagiakan pada diri peserta didik. Pemahaman nilai yang membahagiakan bisa terjalin karena pembelajaran yang di dalamnya tidak ada lagi tekanan, baik tekanan fisik maupun psikis sehingga suasana kelas menjadi menyenangkan dan tidak monoton (Wahono, 2012). Lebih lanjut Wahono mengemukakan bahwa strategi pembelajaran joyful learning adalah suatu proses pembelajaran yang mengasyikkan dan bermakna. Mengasyikkan berarti pembelajaran yang dapat dinikmati oleh peserta didik tanpa adanya tekanan, sedangkan bermakna berarti pengetahuan dan keterampilan yang diperoleh peserta didik dalam pembelajaran dapat bermanfaat dalam kehidupannya (Wahono, 2012). Strategi pembelajaran joyful learning pula berarti suatu kegiatan pembelajaran yang berlangsung di dalam suasana yang menyenangkan dan mengesankan. Suasanapembelajaran yang menyenangkan dan mengesankan akan menarik minat peserta didik untuk terlibat secara aktif dalam kegiatan pembelajaran dalam upaya mencapai tujuan pembelajaran yang telah ditetapkan.

Selain daripada itu Wahono, menjelaskan bahwa strategi pembelajaran joyful learning dalam satu sisi, guru memposisikan dirinya sebagai mitra belajar peserta didik sehingga terdapat kohesi yang kuat antara guru dan peserta didik dalam suasana pembelajaran yang sama tanpa adanya tekanan. Pada sisi yang lain, pembelajaran yang menyenangkan dapat terwujud apabila guru mampu mendesain materi pembelajaran 
dengan baik serta mengkombinasikannya dengan metode pembelajaran yang mengedepankan keterlibatan peserta didik dalam proses pembelajaran (Wahono, 2012). Mungkin saja proses pembelajaran yang berlangsung dapat diaplikasikan melalui video, game, bernyanyi, kuis dan aktivitas-aktivitas lain yang menimbulkan perasaan yang menyenangkan.

Berdasarkan beberapa keterangan di atas dapat dikatakan bahwa strategi pembelajaran joyful learning merupakan strategi untuk membangkitkan minat dan semangat, memacu kreativitas peserta didik yang dilaksanakan dalam suasana yang menyenangkan.

\section{Tujuan Strategi Pembelajaran Joyful Learning}

Tujuan strategi pembelajaran joyful learning dikemukakan oleh Rusman, yakni agar peserta didik memiliki motivasi yang kuat dalam pembelajaran karena pembelajaran diselengggarakan secara nyaman dan menyenangkan dengan melibatkan peserta didik baik fisik maupun psikis. Dalam hal ini guru perlu menciptakan kondisi pembelajaran yang sesuai minat dan kecerdasan peserta didik. Secara khusus tujuan pembelajaran yang menyenangkan adalah menggugah sepenuhnya kemampuan belajar dan memberikan sumbangan sepenuhnya bagi kebahagiaan, kompetensi, kecerdasan dan keberhasilan mereka sebagai peserta didik (Rusman, 2013). Selain daripada itu, Uno mengemukakan bahwa tujuan strategi pembelajaran joyful learning adalah agar guru dapat memunculkan potensi-potensi yang dimiliki peserta didik sehingga dapat mengembalikan fungsi proses pembelajaran ke fitrah awalnya, yakni membangkitkan potensi peserta didik melalui transfer ilmu pengetahuan yang tidak bersifat indoktriner dengan guru sebagai fasilitatornya (Uno, 2011).

Untuk mencapai tujuan strategi pembelajaran joyful learning, ahli pendidikan lain yakni (Mulyasa, 2006) menekankan beberapa faktor yang perlu diperhatikan oleh seorang guru sebagai berikut :

1. Kebermaknaan yakni guru memberikan makna yang berkesan bagi peserta didiknya. Pembelajaran yang bermakna mampu meningkatkan pemahaman peserta didik yang perlu digali melalui pengalaman peserta didik sendiri sehingga pembelajaran dapat meninggalkan kesan yang bermakna bagi peserta didik untuk membantu pemahamannya. 
2. Penguatan yakni dilakukan melalui pengulangan oleh guru maupun latihan peserta didik. Dengan penguatan memori peserta didik melalui pengulangan dan latihan maka dapat menanggulangi proses lupa. Dalam pembelajaran joyful learning, penguatan merupakan hal penting yang perlu dilakukan.

3. Umpan balik yakni kegiatan pembelajaran untuk membuka wawasan dan memberikan kesempatan kepada peserta didik untuk melakukan kontruksi ulang bila terjadi kesalahan pemahaman atau adanya pemahaman yang kurang tepat.

Berdasakan beberapa penjelasan tersebut di atas dapat disimpulkan bahwa tujuan strategi pembelajaranjoyful learningyakni agar peserta didik memiliki motivasi yang kuat dalam pembelajaran karena pembelajaran dilaksanakan dengan menyenangkan sehingga mampu meningkatkan pemahaman peserta didik terhadap suatu materi pembelajaran. Dalam hal ini pembelajaran yang dilakukan meliliki kesan yang bermakna, dengan penguatan dan umpan balik yang dilakukan oleh guru.

\section{Teknik Strategi Pembelajaran Joyful Learning}

Strategi pembelajaran joyful learning diaplikasikan dalam beberapa teknik oleh seorang guru yang profesional. Utami mengemukakan beberapa teknik untuk menciptakan kegiatan pembelajaran yang menyenangkan (Utami, 2013) sebagai berikut:

1. Mengawali kegiatan pembelajaran dengan hal-hal yang menyenangkan. Guru menciptakan suasana riang gembira dalam mengawali kegiatan pembelajaran baik di dalam maupun di luar kelas. Sikap riang gembira dari guru akan berpengaruh besar dalam membangkitkan motivasi peserta didik. Seorang guru yang kreatif tentu dapat menciptakan "kondisi" (ice breaking) yang tepat dalam suasana pembelajaran ataupun mampu mengkondisikan kembali suasana pembelajaran yang mulai membosankan dan melelahkan sehingga kembali kepada suasana yang penuh semangat. Guru harus pula memahami perasaan peserta didiknya. Perasaan memberi kekuatan kepada mereka untuk bertindak sesuai dengan apa yang dipercayainya. Dalam kehidupan sehari-hari peserta didik membutuhkan guru yang dapat memahami perasaannya, namun yang sering terjadi dan sangat memilukan hati peserta didik adalah terabaikannya perasaan peserta didik.

2. Menjauhi berbagai gaya komunikasi yang kurang patut. Gaya komunikasi yang kurang patut, akan berdampak negatif terhadap peserta didik. Terdapat beberapa gaya komunikasi yang kurang patut yang harus dihindari yakni: (a)gaya 
memerintah. Gaya ini paling sering terjadi karena pendidik merasa dirinya memiliki kekuasaan tertinggi di dalam kelas. Peserta didik harus patuh dan taat kepada guru dan siapa yang melanggar akan ditundukkan melalui ancaman. Contoh : Bu guru tidak suka kamu menangis, ayo diam...! Awas...Jika kamu sekali lagi lupa membawa PR, (b) gaya memojokkan/menyalahkan. Gaya ini sering terjadi ketika kesabaran guru sebagai pendidik menjadi tawar, tidak mau mngambil resiko dan tanggung jawab, selalu menuding peserta didik sebagai sumber kesalahan. Contoh : Nah, betulkan, kalau pak guru menerangkan kamu tidak serius, ulanganmu hasilnya jelek semua. Кати sih, malas belajar sehingga nilaimu jelek semua, (c) gaya meremehkan. Gaya ini sering terjadi karena kurangnya pemahaman pendidik terhadap karakteristik dan keunikan masing-masing peserta didik. Guru cenderung meremehkan peserta didik yang kemampuan belajarnya sangat kurang dan menganggapnya sebagai anak bawang, begitu terhadap peserta didik yang usil dan nakal. Contoh : Masa, pelajaran mudah seperti ini kamu tidak dapat mengerjakan. $A h$, kamu duduk di sana saja, biar tidak rebut dan mengganggu, (d) gaya membandingkan. Gaya ini sering terjadi karena pendidik terlalu memiliki harapan yang tinggi dan berlebih-lebihan, seakan-akan kemampuan semua peserta didik sama. Contoh : Apa kalian tidak malu sama kelas lain yang dapat piala. Apa kamu tidak merasa malu sama kakakmu yang selalu juara kelas, (e) gaya mencap termasuk melanggar hak asasi peserta didik. Biasanya gaya ini timbul akibat adanya sepenggal kelakuan yang melekat pada penilaian guru terhadap peserta didik sebelumnya. Contoh : Kamu memang si anak nakal, bandel, tidak tahu aturan, persis seperti kelakuan kakakmu dulu, (f) gaya mengancam. Gaya ini memperlihatkan ketidak matangan dan ketidak siapan pendidikdalam mengahadapi berbagai sikap peserta didik. Pendidik sering mengancam karena tidak mau terlibat berlama-lama dengan kondisi yang tidak diharapkan. Contoh : Hei diam, rebut saja...! Kenapa kamu cengar-cengir Badu, ayo keluar, mengganggu kosentrasi saya saja.

3. Menguasai keterampilan dasar mengajar. Hal tersebut sangat penting karena setiap peserta didik memiliki gaya belajar yang berbeda-beda, maka guru harus mengimbanginya dengan berbagai macam keterampilan mengajar. Terdapat beberapa macam keterampilan mengajar yang harus dimiliki seorang guru yakni 
:(a)keterampilan bertanya memegang peranan yang sangat penting sebab pertanyaan yang tersusun dengan baik dan teknik pelontaran dengan tepat akan memberikan dampak positif terhadap terhadap semangat belajar peserta didik, (b) keterampilan memberi penguatan (reinforcement) merupakan respon terhadap suatu perilaku yang dapat meningkatkan kemungkinan terulangnya kembali perilaku tersebut. Penguatan dapat dilakukan secara verbal, dan non verbal. Penguatan secara verbal berupa kata-kata dan kalimat pujian, seperti bagus, tepat dan lain-lain. Sedangkan secara non verbal dapat dilakukan dengan sentuhan, acungan jempol, dan kegiatan yang menyenangkan, (c) keterampilan mengadakan variasi merupakan keterampilan yang harus dikuasai guru dalam pembelajaran, untuk mengurangi atau menghilangkan kebosanan peserta didik agar selalu antusias, tekun dan penuh partisipasi dalam pembelajaran. Variasi dalam pembelajaran adalah perubahan dalam proses kegiatan yang bertujuan untuk meningkatkan motivasi belajar peserta didik serta mengurangi kejenuhan dan kebosanan, (d) keterampilan menjelaskan yaitu penyajian informasi secara lisan yang diorganisasi secara sistematik untuk menunjukkan adanya hubungan yang satu dengan yang lainnya, misalnya antara sebab dan akibat, defenisi dengan contoh atau dengan sesuatu yang belum diketahui. Penyampaian informasi yang terencana dengan baik dan disajikan dengan urutan yang cocok merupakan ciri utama kegiatan menjelaskan,(e) keterampilan membuka dan menutup pembelajaran yaitu usaha atau kegiatan yang dilakukan oleh guru dalam kegiatan pembelajaran untuk menciptakan prakondisi bagi peserta didik agar mental atau perhatian mereka terpusat pada apa yang dipelajarinya sehingga usaha tersebut memberikan efek yang positif terhadap kegiatan pembelajaran. Kegiatan membuka pembelajaran tidak hanya dilakukan oleh guru pada awal jam pembelajaran, tetapi juga pada awal setiap penggal kegiatan inti pembelajaran yang diberikan selama jam pelajaran itu. Hal tersebut dapat dilakukan dengan cara mengemukakan tujuan yang akan dicapai, menarik perhatian peserta didik, memberi acuan dan membuat kaitan antara materi pelajaran yang telah dikuasai oleh peserta didik dengan bahan yang akan dipelajarinya, (f) keterampilan membimbing diskusi yaitu suatu proses yang teratur dan melibatkan sekelompok orang dalam interaksi tatap muka untuk mengambil kesimpulan dan memecahkan masalah, (g) keterampilan mengelola kelas yaitu keterampilan guru 
untuk menciptakan dan memelihara kondisi belajar yang optimal dan mengembalikannya bila terjadi gangguan dalam proses pembelajaran atau kegiatan untuk menciptakan atau mempertahankan kondisi optimal bagi terjadinya proses pembelajaran, misalnya penghentian tingkah laku peserta didik yang mengganggu perhatian, pemberian ganjaran bagi ketepatan waktu penyelesaian tugas oleh peserta didik, dan penetapan norma kelompok yang produktif, (h) keterampilan mengajar kelompok kecil dan perorangan yaitu suatu bentuk pembelajaran yang memungkinkan guru memberikan perhatian terhadap setiap peserta didik dan mengadakan interaksi antara guru dan peserta didik maupun sesama peserta didik. Melakukan pembelajaran perorangan, perlu diperhatikan kemampuan dan kematangan berpikir peserta didik agar apa yang disampaikan bisa diserap dan diterima oleh peserta didik. Jadi dalam pembelajaran guru selain memberikan perhatian pada kelompok juga harus memperhatikan peserta didik secara perorangan. Hal tersebut dilakukan karena setiap peserta didik mempunyai gaya belajar dan daya serap yang berbeda-beda. Dengan adanya perhatian guru terhadap kelompok dan perorangan, maka diharapkan apa yang disampaikan oleh guru dapat diserap dan diterima peserta didik dengan baik.

4. Menggunakan media pembelajaran. Media pembelajaran dapat mempertinggi motivasi peserta didik dan pada gilirannya diharapkan dapat mempertinggi hasil belajar peserta didik. Ada beberapa alasan bahwa media pembelajaran dapat mempertinggi minat peserta didik dalam pembelajaran yakni : (a) pembelajaran akan lebih menarik perhatian peserta didik sehingga dapat menumbuhkan motivasi belajar,(b) bahan pembelajaran akan lebih jelas maknanya sehingga dapat lebih dipahami oleh peserta didik dan memungkinkan peserta didik menguasai tujuan pembelajaran lebih baik,(c) metode mengajar akan lebih bervariasi, tidak sematamata komunikasi verbal melalui penuturan kata-kata oleh guru sehingga peserta didik tidak bosan dan guru tidak kehabisan tenaga,(d) peserta didik lebih banyak melakukan kegiatan pembelajaran sebab tidak hanya mendengarkan uraian guru tetapi juga aktivitas lain seperti mengamati, mendemonstrasikan dan lain-lain.

5. Menggunakan metode pembelajaran yang bervariasi. Dalam kegiatan pembelajaran, metode mempunyai kedudukan yang sangat penting dalam upaya pencapaian tujuan pembelajaran karena metode menjadi sarana yang memberi makna bagi materi yang 
tersusun dalam kurikulum pendidikan sedemikian rupa, sehingga dapat dapat dipahami atau diserap oleh peserta didik. Tanpa metode, suatu materi pelajaran tidak akan berproses secara efektif dan efisien dalam kegiatan pembelajaran. Metode pembelajaran yang tidak tepat pula akan menjadi penghalang dalam kelancaran proses pembelajaran sehingga banyak tenaga yang terbuang dengan siasia. Oleh karenaitu, metode yang ditetapkan oleh guru dapat berdaya guna dan berhasil guna jika mampu dipergunakan untuk mencapai tujuan pendidikan yang telah ditetapkan.

6. Belajar dengan melakukan (learning by doing). Pada hakikatnya peserta didik senang apabila belajar sambil bekerja atau melakukan aktivitas. Peserta didik akan punya harga diri apabila diberi kesempatan untuk berbuat atau melakukan sesuatu. Untuk itu, peserta didik perlu diberi kesempatan untuk melakukan kegiatan nyata yang melibatkan otot dan pikirannya, sehingga mereka belajar bagaimana cara belajar menemukan, mencari dan menyelesaikan permasalahan. Lebih dari 2.400 tahun yang lalu Confucius menyatakan :Apa yang saya dengar, saya lupa.Apa yang saya lihat, saya ingat.Apa yang saya lakukan, saya paham.Tiga pernyataan sederhana ini membicarakan bobot penting belajar aktif.

Sejalan dengan beberapa keterangan di atas, dikemukakan pula teknik strategi pembelajaran joyful learning oleh (Catur, 2017) sebagai berikut :

1. Teknik persiapan meliputi: (a) mengajak peserta didik keluar dari keadaan mental yang pasif, (b) menyingkirkan rintangan belajar, (c) merangsang minat dan ingin tahu peserta didik, ( d) memberi peserta didik perasaan positif mengenai hubungan yang bermakna dengan topik pembelajaran, (e) menjadikan peserta didik aktif yang tergugah untuk berpikir, ( f) mengajak peserta didik keluar dari keterasingan dan masuk ke dalam komunitas belajar.

2. Teknik penyampaian dengan mengajak peserta didik terlibat penuh dalam proses pembelajaranyang meliputi : (a) presentase guru, (b) presentase guru dan peserta didik, (c) presentase peserta didik dalam berlatih menemukan.

3. Teknik pelatihan dengan cara meminta peserta didik membicarakan apa yang mereka alami dan apa yang mereka butuhkan untuk meningkatkan prestasinya.

4. Teknik penutup yakni guru memberikan penguatan terhadap materi pembelajaran. 
Berdasarkan beberapa teori yangtelah dikemukakan di atas dapat disimpulkan bahwa strategi pembelajaran joyful learning dapat diaplikasikan oleh guru melalui teknik-teknik pembelajaran untuk memberikan motivasi atau dorongan yang kuat kepada peserta didik baik dari segi fisik maupun psikis sehingga peserta didik dapat melaksanakan pembelajaran dalam suasana yang menyenangkan. Hal tersebut dapat terlaksana dengan baik apabila guru menguasai teknik-teknik pembelajaran dan mampu mengaplikasikannya dalam kegiatan pembelajaran yang dilaksanakan.

\section{Langkah-Langkah Strategi Pembelajaran Joyful Learning}

Catur (2017) berpendapat bahwa strategi pembeajaranjoyful learning dapat mempercepat penguasaan dan pemahaman materi pelajaran yang dipelajari, sehingga waktu yang dibutuhkan untuk belajar lebih cepat.Berkaitan dengan penjelesantersebut, strategi pembelajaran joyful learning memiliki langkah-langkah dalampelaksanaannya. Catur mengemukakan langkah-langkah dalam pembelajaran joyful learning (Catur, 2017) sebagai berikut :

1. Guru menjelaskan materi dengan gambar, gerakan dan tanya jawab.

2. Peserta didik dibagi menjadi beberapa kelompok kecil untuk diajak bermain dan bernyanyi.

3. Guru mengajak peserta didik bernyanyi atau tepuk-tepuk yang dibuat sendiri oleh guru (guru harus kreatif membuat ringkasan materi untuk dijadikan suatu lagu ataupun tepuk-tepuk).

4. Setiap kelompok diberi soal latihan untuk didiskusikan.(usahakan dengan media pembelajaran).

5. Guru menunjuk kelompok untuk membacakan jawaban hasil diskusinya dengan permainan.

6. Guru memberi penguatan atas jawaban yang telah disampaikan oleh masing-masing kelompok.

7. Guru mengajak peserta didik untuk bermain dengan permainan yang sesuai dengan materi yang sedang dipelajari.

8. Guru memberi hadiah kepada kelompok yang terbaik dan memperoleh point terbanyak. 
Sementara Sholikhah memgemukakan pula langkah-langkah strategi pembelajaran joyful learning (Sholikhah, 2012) sebagai berikut :

1. Tahap persiapan yaitu mengajak peserta didik keluar dari keadaan mental yang pasif, menyingkirkan rintangan belajar, merangsang minat dan ingin tahu peserta didik, memberi peserta didik perasaan positif untuk menguasai pembelajaran, menjadikan peserta didik aktif, tergugah untuk berpikir dan mengajak peserta didik untuk keluar dari keterasingan dan masuk dalam komunitas belajar.

2. Tahap penyampaian yaitu siklus untuk mempertemukan proses pembelajaran dengan materi pembelajaran secara positif dan menarik. Pada tahap ini pula guru menyampaikan materi pembelajaran yang dikaitkan dengan hal-hal nyata dalam kehidupan sehari-hari dan diasosiasikan dengan apa yang sudah diketahui dan diingat oleh peserta didik sebelumnya.

3. Tahap pelatihan yaitu meminta peserta didik berulang-ulang mempraktekan suatu keterampilan dan memberikan umpan balik. Peserta didik pula diminta untuk membericarakan apa yang mereka alami dan apa saja yang dapat meningkatkan prestasinya. Pembelajaran dibuat seolah-olah peserta didik sedang bermain dan untuk meningkatkan aktivitas peserta didik maka guru dapat memberikan humor dalam proses pembelajaran.

4. Tahap penutup yaitu guru memberikan penguatan pada materi yang telah diterima peserta didik dengan memusatkan perhatiannya. Penguatan dalam tahap ini dilakukan dengan meminta peserta didik membuat kesimpulan berupa kata-kata, lagu ataupun pantun.

Dari penerapan langkah-langkah strategi pembelajaran joyful learning tersebut, maka guru hendaknya memotivasi tumbuhnya harga diri peserta didik dengan menghargai kontribusi, gagasan, ide dari mereka serta memberi rasa aman (fisik dan psikis) dalam lingkungan pembelajaran. Dengan demikin peserta didik akan merasa senang untuk terlibat secara fisik dan psikis dalam proses pembelajaran dan dapat mengggugah serta memberikan sumbangan sepenuhnya pada penajaman kecerdasan, kompetensi dan kebahagiaan mereka sebagai peserta didik.

\section{Urgensi Strategi Pembelajaran Joyful Learning}

Dalam keseluruhan proses pendidikan di sekolah/madrasah, pembelajaran merupakan aktivitas yang paling utama karena keberhasilan pencapaian tujuan 
pendidikan banyak ditentukan oleh pelaksanaan pembelajaran yang berlangsung di sekolah/madrasah. Searah dengan pernyataan tersebut, Indrawati dan Setiawan mengemukakan bahwa konsentrasi yang tinggi meningkatkan hasil belajar. Dalam penelitian mengenai otak dan pembelajaran menungkapkan fakta yang mengejutkan yakni apabila sesuatu dipelajari sungguh-sungguh (dimana perhatian yang tinggi dari seorang tercurah) maka struktur sistem syaraf seseorang berubah. Di dalam diri seseorang tercipta hal-hal baru seperti jaringan syaraf baru, jalur elektris baru, asosiasi baru, dan koneksi baru (Setiawan \& Wawan, 2009).

Searah dengan pernyataan tersebut, Budiningsih menjelaskan pula bahwa tentu saja konsentrasi yang tinggi tidak akan terwujud jika kondisi kelas tidak nyaman. Oleh karena itu, manajemen kelas sangat diperlukan agar peserta didik mampu melakukan kontrol terhadap pemenuhan kebutuhan emosionalnya. Lingkungan belajar yang demokratis memberi kebebasan kepada peserta didik untuk melakukan pilihan-pilihan tindakan belajar dan akan mendorong peserta didik untuk terlibat secara fisik, emosional dan mental dalam proses pembelajaran, sehingga akan dapat memunculkan kegiatankegiatan yang kreatif, efektif dan produktif (Budiningsih, 2012). Demikian pula sebaliknya, prakarsa peserta didik untuk belajar akan mati apabila dihadapkan pada berbagai macam aturan yang tak ada kaitannya dengan belajar. Banyaknya aturan yang sering kali dibuat oleh guru dan harus ditaati oleh peserta didik dan akan menyebabkannya selalu diliputi rasa takut. Lebih jauh lagi, peserta didik akan kehilangan kebebasan berbuat dan melakukan kontrol diri. Yang terjadi jika peserta didik selalu diliputi oleh rasa takut adalah peserta didik akan mengembangkan pertahanan diri (defence mechanism), sehingga yang dipelajari bukanlah pesan-pesan pembelajaran, melainkan cara-cara untuk mempertahankan diri mengatasi rasa takut. Peserta didik demikian tidak akan mengalami growth inlearning, dan akan selalu menyembunyikan ketidakmampuannya.

Masih sering dijumpai dalam proses pembelajaran,terperangkap dalam tradisi yang mengukung kreativitas peserta didik. Seperti kebiasaan yang selalu dilakukan oleh guru ketika masuk kelas, dimana ketua kelas memberikan aba-aba dengan kata-kata : duduk yang rapih, tangan di meja, mulut dikunci. Memang sepintas kebiasaan tersebut terlihat baik karena suasana kelas menjadi hening dan tidak gaduh, tetapi suasana tersebut mempengaruhi keleluasaan peserta didik dalam berekspresi dan 
mengemukakan pendapat. Peserta didik menjadi takut dan lebih banyak menerima dari guru ketimbang aktif dalam pembelajaran. Memang kelihatannya, guru merasa sukses karena peserta didiknya memperhatikan dengan seksama penjelasan guru. Tetapi setuasi demikian membuat proses pembelajaran berlangsung kaku dan berasal dari satu arah yakni dari seorang guru. Hal tersebut berimplikasi pada proses pembelajaran yang tidak efektif dan hasil belajar yangtidak tuntas.

Guru memiliki tugas dan tanggung jawab untuk menciptakan suasana pembelajaran yang menyenangkan. Usman mengemukakan beberapa hal (Usman, 2011) sebagai berikut :

1. Menyapa peserta didik dengan ramah dan bersemangat. Menciptakan awal pembelajaran yang berkesan adalah penting karena akan mempengaruhi proses selanjutnya. Jika awalnya baik, menarik, dan memikat, maka proses pembelajaran akan lebih hidup dan menggairahkan. Oleh karena itu, guru harus selalu mengawali kegiatan pembelajaran dengan memberikan sapaan hangat kepada peserta didik. misalnya "anak-anak...bu guru senang bertemu kalian hari ini, kalian adalah anakanak ibu yang hebat". Sapaan hangat dan raut wajah cerah akan memantulkan energi positif yang dapat mempegaruhi semangat peserta didik dalam proses pembelajaran.

2. Menciptakan suasana rileks. Guru harus menciptakan lingkungan belajar yang releks atau lingkungan belajar yang nyaman. Oleh karena itu, posisi tempat duduk perlu diatur secara berkala sesuai keinginan peserta didik. Bisa memakai format $U$, lingkaran, cevron, dan lain-lain. Selain itu, ciptakanlah suasana kelas dimana peserta didik tidak takut melakukan kesalahan. Untuk menanamkan keberanian kepada peserta didik dalam mengemukakan pendapat atau menjawab pertanyaan, katakan kepada peserta didik bahwa kesalahan adalah suatu yang lumrah dan tidak berdosa.

3. Memotivasi peserta didik yakni sebuah konsep utama dalam banyak teori pembelajaran. Motivasi ini sangat berkaitan dengan dorongan, perhatian, kecemasan, dan umpan balik/penguatan. Adanya dorongan dalam diri individu untuk belajar bukan hanya tumbuh dari dirinya secara langsung, tetapi bisa saja karena rangsangan dari luar, misalnya berupa stimulus model pembelajaran yang menarik, memungkinkan respon yang baik dari diri peserta didik yang akan belajar. 
Respon yang baik tersebut, akan berubah menjadi sebuah motivasi yang tumbuh dalam dirinya sehingga peserta didik merasa terdorong untuk mengikuti proses pembelajaran dengan penuh perhatian dan antusias.Apabila dalam diri peserta didik telah tumbuh respon, hingga termotivasi untuk belajar, maka tujuan belajar akan lebih mudah dicapai. Peserta didik yang antusias dalam proses pembelajaran memiliki kecenderungan berhasil lebih besar dibanding mereka yang mengikuti proses dengan terpaksa atau asal-asalan. Terkadang, guru dalam melaksanakam tugasnya, hanya untuk mengejar target tanpa memperdulikan pemahaman peserta didik, padahal belajar adalah suatu bentuk aktivitas manusia yang memerlukan adanya motivasi untuk mencapai tujuan. Semakin tinggi motivasi yang didapat peserta didik, maka semakin tinggi pula keberhasilan yang akan dicapai.Banyak cara dalam memberikan motivasi kepada peserta didik antara lain dengan membuat yel-yel berupa kata-kata afirmasi seperti dialog yakni :Guru : Apa Kabar ?Peserta didik : Kabar baik !Guru : Apakah kalian suka belajar ?Peserta didik : ya kami suka !Guru : seberapa suka ? Peserta didik : sangat suka !Guru : untuk apa kalian belajar ? Peserta didik :agar pintar !Guru : seberapa pintar ?Peserta didik : sangat pintar !Guru pula dapat membuat kata-kata afirmasi sendiri yang disesuaikan dengan harapan yang dinginkan dari kata-kata tersebut. Misalnya guru menginginkan agar peserta didiknya memperlakukan guru dengan hormat maka dapat membiasakan kalimat ini bagi peserta didik yakni : Guru : apakah kalian murid yang baik? Peserta didik : ya kami murid yang baik! Guru : bagaimana kalian memperlakukan guru? Peserta didik : dengan hormat. Guru : seberapa hormat ? Peserta didik : sangat hormat !Kata-kata afirmasi tersebut dapat digunakan pada awal, pertengahan, atau penutupan pembelajaran dan dapat pula digunakan secara berulang-ulang sehingga kata-kata tersebut menghujam ke hatinya sehingga melahirkan sikap yang positif sesuai dengan kata-kata afirmasi itu sendiri.

4. Menggunakan ice breaking. Dalam pelajaran terkadang kita melihat timbulnya suasana yang kurang mendukung hingga menyebabkan tidak tercapainya tujuan pembelajaran. Suasana yang dimaksud adalah kaku, dingin, atau beku sehingga pembelajaran saat itu menjadi kurang nyaman. Icebreaking berguna untuk menaikkan kembali derajat perhatian peserta pelatihan (training). Hal ini perlu dilakukan oleh guru karena berdasarkan hasil penelitian, rata-rata setiap orang 
untuk dapat berkonsentrasi pada satu fokus tertentu hanyalah sekitar 15 menit. Setelah itu konsentrasi seseorang sudah tidak lagi dapat memusatkan perhatian (fokus). Seorang guru harus peka ketika melihat gejala yang menunjukkan bahwa peserta didik sudah tidak konsentrasi lagi. Dengan demikian guru perlu melakukan ice breaking agar peserta didik dapat berkonsentrasi kembali dalam proses pembelajaran. Ice breaking bisa berupa yel-yel, tepuk tangan, menyanyi, gerak dan lagu, gerak anggota badan, games dan lain-lain.

5. Menggunakan metode yang variatif. Peserta didik adalah makhluk yang unik memiliki kecenderungan, kecerdasan, dan gaya belajar yang berbeda-beda. Paling tidak ada 4 gaya belajar peserta didik yaitu auditory, visual, reading dan kinesthetik. Guru perlu menyadari bahwa peserta didik dalam satu kelas memiliki gaya belajar yang berbeda-beda. Oleh karena itu, untuk mengakomodir semua peserta didik untuk belajar dengan latar belakang yang berbeda tersebut, guru dapat menggunakan metode yang bervariasi.

Untuk mendukung teori-teori tersebut di atas, beberapa metode praktis sebagai implementasinya, dikemukakan oleh Ismail yang dapat diterapkan (Ismail, 2008) sebagai berikut :

1. Every one is a teacher here, dalam metode ini setiap peserta didik bertindak sebagai guru. Setiap peserta didik menuliskan sebuah pertanyaan pada selembar kertas tentang materi pokok yang telah atau sedang dipelajari. Pertanyaan tersebut dikumpulkan dan diacak kemudian dibagikan kembali kepada peserta didik. Diupayakan kertas yang dikembalikan tersebut tidak kembali kepada yang membuat pertanyaan semula. Kemudian peserta didik diminta untuk membacakan pertanyaan yang ada padanya dan menjawabnya sesuai dengan kemampuannya dan selanjutnya diberikan kesempatan kepada peserta didik yang lain untuk menambahkan jawabannya.

2. The power of two and four yakni guru menetapkan satu masalah atau pertanyaan terkait dengan materi yang telah atau sedang dipelejari. Setiap peserta didik diminta memikirkan jawabannya masing-masing,kemudian mencari pasangan untuk mendiskusikannya. Setelah berdiskusi dengan pasangannya masing-masing, peserta didik diminta untuk membuat kelompok dimana masing-masing kelompok terdiri dari 4 orang. Setiap kelompok kembali mendiskusikan persoalan yang sama. 
3. Card sort,dalam metode ini, guru menyiapkan kartu berisi tentang materi pokok yang telah atau sedang dipelajari. Isi kartu terdiri dari kartu induk (topik utama) dan kartu rincian. Seluruh kartu diacak kemudian dibagikan kepada setiap peserta didik. Arahkan kepada peserta didik untuk bergerak mencari kartu induknya. Setelah ketemu kartu induknya, peserta didik secara otomatis akan membuat kelompok sesuai dengan topik atau kartu induknya dan menyusun rincian sesuai dengan urutannya masing-masing. Guru kemudian mengecek apakah ada peserta didik yang salah masuk kelompok atau salah dalam mengurutkan rinciannya.

4. Reading aloud yakni guru memilih sebuah teks yang menarik sesuai dengan topik pembelajaran yang dibagi dalam potongan-potongan kertas untuk dibaca dengan keras oleh peserta didik secara bergantian. Ketika bacaan-bacaan tersebut berjalan, guru menghentikan di beberapa tempat untuk menekankan poin-poin tertentu, kemudian guru memunculkan beberapa pertanyaan, atau memberikan contohcontoh. Guru dapat membuat diskusi-diskusi singkat jika peserta didik menunjukan minat dalam bagian tertentu.

Guru hendaknya menyadari bahwa pembelajaran yang menyenangkan dapat meningkatkan keberhasilan dalam proses pembelajaran. Oleh karena itu, guru hendaknya dapat menciptakan suasana yang menyenangkan dalam setiap proses pembelajaran. Beberapa cara yang dapat digunakan oleh guru untuk menciptakan pembelajaran yang menyenangkan antara lain dengan menambahkan ice bereaking dalam proses pembelajaran, metode yang bervariasi, menciptakan suasana yang rileks, memotivasi dan menyapa peserta didik dengan hangat dan antusias. Dalam konteks pembelajaran menyenangkan guru dituntut tidak hanya memerankan diri sebagai pengajar atau pendidik, tetapi juga sebagai fasilitator dan motivator bagi peserta didik. Salah satu alternatif model pembelajaran yang diharapkan dapat menciptakan kondisi belajar yang menyenangkan, tanpa beban, dan aktif melibatkan siswa adalah Joyful Learning atau pembelajaran menyenangkan. Joyful Learning merupakan strategi pembelajaran untuk mengembangkan keterampilan dan pemahaman siswa, dengan penekanan pada belajar sambil bekerja learning by doing) (Aprilia Intan Permatasari1, 2014). 


\section{Strategi Pembelajaran Joyful Learning Sebagai Upaya Meningkatkan Mutu Pembelajaran}

Sebagaimana telah dijelaskan pada bagian terdahulu bahwa strategi pembelajaran joyful learning merupakan konsep dan strategi pembelajaran yang merupakan perpaduan dari pembelajaran bermakna, kontekstual, kontruktivisme, pembelajaran aktif dan psikologi perkembangan peserta didik. Dengan demikian, penekanan konseptualnya sangat relevan dengan perkembangan moral dan kejiwaan peserta didik sesuai dengan bakat dan minatnya dengan berbagai topik bahasan yang sedang berlangsung dan berkembang di sekolah maupun di masyarakat. Peserta didik dapat belajar dari lingkungannya, baik lingkungan fisik maupun lingkungan sosialnya (contextual teaching and learning). Peserta didik juga merasa senang dan bergembira karena memulainya dari sesuatu yang telah dimilikinya sendiri sehingga timbul rasa percaya diri (confidence) dan itu akan menimbulkan perasaan dihargai dan diakui yang dapat menyenangkan dirinya sesuai dengan ciri-ciri perkembangan fisiologis dan psikologis peserta didik. Kenyataan tersebut pula pada gilirannya akan memotivasi peserta didik untuk terlibat secara aktif dalam proses pembelajara karena atmosfir pembelajaran (academic atmosfir) sesuai dengan kepentingan yang diciptakannya. Dalam beberapa penelitian menunjukan keaktifan siswa dalam pelaksanaan pembelajaran berbasis joyfull learning lebih tinggi daripada persentase keaktifan siswa pada pembelajaran ekspositori, dan aktivitas guru dalam mengelola pembelajaran berbasis joyfull learning mencapai kriteria sangat baik (Triastuti, 2014).

Dalam strategi pembelajaran joyful learning dapat dilakukam seiring dengan belajar sambil bermain yang berimplikasi pada pembelajaran aktif, kreatif, efektif dan menyenangkan. Sambil bermain, peserta didik aktif belajar, dan sambil aktif belajar, peserta didik aktif bermain. Dalam bermain mereka mendapatkan manfaat atau kegunaan esensi suatu pengetahuan dan keterampilan dan sambil belajar mereka melakukan refreshing agar kondisi kejiwaan setiap peserta didik tetap dalam suasana yang rileks. Dengan demikian dapat dipahami bahwa pembelajaran adalah membangun pengalaman belajar peserta didik dan pengetahuan baru. Sedangkan menyenangkan dimaksudkan agar guru mampu menciptakan suasana pembelajaran yang tidak membosankan, sehingga peserta didik mampu memusatkan perhatiannya dalam kegiatan pembelajaran untuk meningkatkan mutu pembelajaran. 


\section{Penutup}

Berdasarkan beberapa uraian tersebut di atas, maka dapat disimpulkan bahwa salah satu upaya guru untuk meningkatkan mutu pembelajaran adalah menerapkan strategi pembelajaran joyful learning. Strategi pembelajaran joyful learning menekankan pada proses pembelajaran yang menyenangkan sehingga peserta didik merasa senang dalam mengikuti proses pembelajaran. Dalam proses pembelajaran yang menyenangkan terdapat sebuah kohesi yang kuat antara pendidik dan peserta didik tanpa ada perasaan terpaksa atau tertekan dalam pelaksanaan pembelajaran. Yang terjadi dalam pembelajaran menyenangkan adalah pola hubungan baik dengan memposisikan peserta sebagai subyek dalam pembelajaran. Guru bukan sebagai satusatunya sumber dalam pembelajaran tapi menjadikan peserta didik sebagai mitra dalam prosespembelajaran. Pembelajaran yang dirancang dengan menyenangkan akan menimbulkan motivasi belajar peserta didik. Selain daripada itu suasana pembelajaran akan terbangun secara demokratis dan peserta didik merasa senang karena keinginan, keberadaan dan otonominya sebagai subyek dalam pembelajaran diakomodasi oleh guru.

Penerapan strategi pembelajaran joyful learning berimplikasi pada peningkatan kualitas proses pembelajaran peserta didik. Proses pembelajaran memiliki kualitas yang baik apabila penerapannya berjalan secara aktif dan menyenangkan yaitu bentuk pembelajaran yang memungkinkan peserta didik berperan secara aktif dalam berinteraksi baik kepada guru sebagai pendidik maupun sesama peserta didik. Selain daripada itu, penerapan strategi pembelajaran joyful learning memiliki implikasi pada peningkatan hasil belajar yakni terjadinya perubahan tingkahlaku peserta didik yang dapat diamati dan diukur dalam bentuk pengetahuan, sikap dan keterampilan sebagai indikator-indikator kompotensi yang dicapai.

\section{DAFTAR PUSTAKA}

Andreas Putra, A. T., Sufiani, \& Jahada. (2020). Transformasi Nilai Pendidikan Islam Anak di PAUD Sultan Qaimuddin Kendari Pada Masa Pandemic Covid 19. Murhum: Jurnal Pendidikan Anak Usia Dini, 1(1), 79-90. https://doi.org/10.37985/murhum.v1i1.8

Anhusadar, L. O., \& Wulandari, H. (2019). Pengembangan Model Pembelajaran Seni Berbasis Agama Pada Anak Usia Dini. Al-Athfaal: Jurnal Ilmiah Pendidikan Anak 
Usia Dini, 2(1), 58-68. https://doi.org/10.24042/ajipaud.v2i1.4622

Aprilia Intan Permatasari1, B. M. (2014). Efektivitas Penggunaan Model Pembelajaran Joyful Dan Metode Pemberian Tugas Terhadap Prestasi Belajar Siswa. JPK, 117-122.

Budiningsih, A. C. (2012). Belajar dan Pembelajaran. Bumi Aksara.

Catur, C. (2017). joyful learning. Joyful learning.Http://Chatarinacatur.Wordpress.Com /2008/10/15/ Joyful Learning.Tanggal 20 April 2021.

Departemen Agama RI. (2006). Undang-Undang dan Peraturan Pemerintah RI tentang Pendidikan. DIRJEN PENDIS.

Ismail, S. M. (2008). Pembelajaran Agama Islam Berbasis PAIKEM. Rasail Media Group.

Laksmi, M., \& Dewi. (2009). Strategi Pembelajaran. Dirjen PAIS.

Mulyasa. (2006). Menjadi Guru Profesional Menciptakan Pembelajaran Kreatif dan Menyenangkan. Remaja Rosda Karya.

Rusman. (2013). Model-Model Pembelajaran. Raja Grafindo Persada.

Setiawan, I., \& Wawan. (2009). Pembelajaran Aktif, Kreatif, Efektif danMenyenangkan. Pusat Pengembangan dan Pemberdayaan Pendidik.

Sholikhah, A. (2012). Penerapan Metode Pembelajaran Berbasis Joyful learning Untuk Meningkatkan Kualitas Proses dan Hasil Belajar Siswa Kelas IV SDN 17 Surakarta. Universitas Muhammadiyah Surakarta.

Triastuti, R. (2014). Keefektifan Model Circ Berbasis Joyfull Learning Terhadap Kemampuan Penalaran Matematis Siswa SMP. Unnes Journal of Mathematics Education.

Uno, H. B. (2011). Perencanaan Pembelajaran. Bumi Aksara.

Usman, M. Z. (2011). Menjadi Guru Profesional. Remaja Rosda Karya.

Utami, D. F. (2013). Belajar Mengajar yang Menyenangkan. Tiga Serangkai.

Wahono, S. (2012). Strategi dan Model Pembelajaran. Indeks Permata Puri Media. 